\title{
Case Report \\ Paraganglioma Presenting as a Nasal Septal Mass: Case Report and Literature Review
}

\author{
James H. Kim (D), ${ }^{1}$ Nathan Tu, ${ }^{2}$ and Bozena Barbara Wrobel ${ }^{3}$ \\ ${ }^{1}$ Keck School of Medicine of the University of Southern California, Los Angeles, CA, USA \\ ${ }^{2}$ University of Southern California LAC+USC Medical Center Department of Otolaryngology, Los Angeles, CA, USA \\ ${ }^{3}$ Associate Professor of Clinical Otolaryngology Head and Neck Surgery, Keck School of Medicine, Los Angeles, CA, USA \\ Correspondence should be addressed to James H. Kim; kim883@usc.edu
}

Received 7 August 2018; Accepted 19 November 2018; Published 6 December 2018

Academic Editor: Richard T. Miyamoto

Copyright (C) 2018 James H. Kim et al. This is an open access article distributed under the Creative Commons Attribution License, which permits unrestricted use, distribution, and reproduction in any medium, provided the original work is properly cited.

\begin{abstract}
Objectives. To describe a rare case of a paraganglioma arising from the nasal septum and review the diagnosis and management of paragangliomas in the nasal cavity and paranasal sinuses. Methods. We present a case of a 70-year-old female presenting with persistent nasal congestion and obstruction. Nasal endoscopy revealed a posterior septal mass approaching the sphenoid sinuses and partially obstructing the nasopharynx. A biopsy of the mass was taken, and histologic analysis confirmed a diagnosis of paraganglioma. Results. The patient underwent an endoscopic resection of the tumor. There has been no evidence of disease recurrence after 3 months of follow-up. Conclusions. Paragangliomas arising from the nasal septum are exceedingly rare, but should be considered in the differential diagnosis in patients presenting with nasal septal masses. These tumors are typically benign, although few cases of malignant sinonasal paragangliomas have been reported. Treatment requires surgical excision with close follow-up as several cases of tumor recurrence have been reported.
\end{abstract}

\section{Introduction}

Paragangliomas are rare, slow-growing neuroendocrine tumors arising from cells of neural crest origin. They typically originate from the adrenal gland, but occur extraadrenally in $5-10 \%$ of cases [1]. In the head and neck region, paragangliomas make up only $0.6 \%$ of all tumors, most commonly in the carotid body and jugular-tympanic regions [1-3]. Though rare, there are few reported cases of paragangliomas arising in the nasal cavity and paranasal sinuses [4-8]. To our knowledge, there has only been one previously reported case of a paraganglioma originating from the nasal septum [8].

\section{Case Report}

A 70-year-old female complaining of persistent nasal congestion and obstruction presented to our clinic for evaluation. She denied any headache or epistaxis. Nasal endoscopy was performed which showed a posterior septal mass approaching the sphenoid sinuses bilaterally and partially obstructing the view of the nasopharynx. The overlying mucosa was intact except for a small area superiorly which showed a soft granulomatous mass protruding into the left nasal cavity.

The patient was taken to the operating room for septoplasty with biopsy of the mass at an outside institution. Microscopic examination of the biopsy specimen demonstrated clusters of epithelioid-appearing cells separated by bands of fibrillary stroma. The epithelioid cells were noted to have abundant amphophilic cytoplasm, uniform, rounded nuclei with "salt and pepper" chromatin, and small nucleoli. No mitotic activity, invasion, necrosis, or calcification was seen. Immunohistochemical staining demonstrated positivity for neuron-specific enolase (NSE), chromogranin A, synaptophysin, and CD56 cell markers within the epithelioid cells. Fibrillary cells were positive for NSE, chromogranin A, S-100, glial fibrillary acid protein (GFAP), and CD56 cell 
markers. Based on the histological appearance and immunohistochemical staining, a diagnosis of paraganglioma was made.

The patient was referred to our institution for further management. Preoperative CT imaging showed a smoothly marginated, soft tissue density mass centered at the posterior nasal septum with extension into the nasopharynx and bulging into the right sphenoid sinus (Figure 1). Severe thinning and smooth remodeling of the anterior wall of the sphenoid sinus and anterior clivus were seen. MRI imaging demonstrated hyperintense signaling of the mass on T1weighted images with a peripheral rim of hypointense signaling on T2-weighted imaging suggestive of a capsule.

An endoscopic resection of the mass was performed. Intraoperatively, a large mass was seen in the posterior aspect of the septum, bulging into the bilateral nasal cavities and extending into the sphenoid sinuses (Figure 2). Erosion of the bone of the rostrum and anterior face of the sphenoid were also seen. Complete resection of the mass was achieved through a posterior septectomy and bilateral sphenoidotomy with tissue removal. Postoperative histologic analysis of the specimen was consistent with a paraganglioma (Figure 3).

The patient has been symptom free without local recurrence 3 months following tumor resection.

\section{Discussion}

Paragangliomas arising from the nasal cavity and nasal sinuses are extremely rare. Only 48 total cases of paragangliomas occurring in the nasal cavity or paranasal sinuses have been reported to date, occurring in patients with ages ranging between 8 and 89 years old, with an average age of 49 years old. These tumors are slightly more prevalent amongst females $(60.4 \%)$. Twelve were reported to be malignant in nature, demonstrating either intracranial extension or metastasis to the cervical lymph nodes, brain, and bone. These masses were most frequently reported to originate from the ethmoid sinuses, middle turbinate, and maxillary sinuses. Other less common locations of origin reported include the superior and inferior turbinates, and the sphenoid and frontal sinuses. To the best of our knowledge, there has only been one other reported case of a paraganglioma originating from the nasal septum (Table 1) [8].

The most commonly reported symptoms included nasal obstruction, headache, and recurrent epistaxis. The vast majority of reported cases were functionally inactive, with no evidence of catecholamine or adrenocorticotropic hormone (ACTH) secretion. However, there have been a few reported cases of metabolically active tumors secreting ACTH and catecholamines, causing hypertension and other cushingoid features in the affected patient $[12,13,30]$. As such, testing for catecholamine and metanephrines is recommended in symptomatic patients $[29,33]$.

The origin of paragangliomas in the nasal cavity and paranasal sinuses remains unclear. Although paraganglionic tissue has never been demonstrated in the nasal cavity, a wider distribution of paraganglionic tissue is thought to exist in fetuses and neonates, degenerating after birth [42, 43]. Some authors have suggested that the migration of these

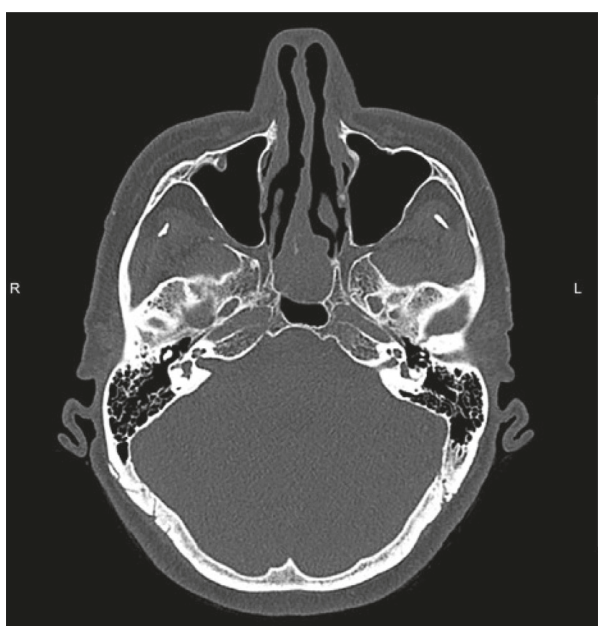

Figure 1: Axial CT image showing a soft tissue mass centered at the posterior nasal septum with extension into the nasopharynx.

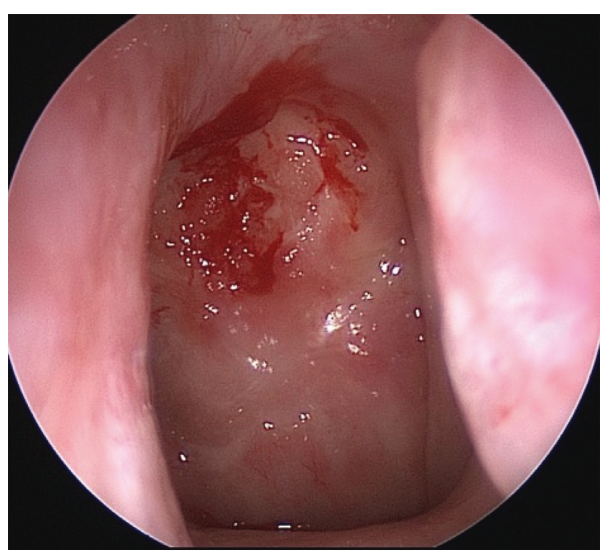

FIgURE 2: Intraoperative image of the mass protruding from the posterior septum within the left nasal cavity.

embryonic paraganglionic cells accounts for the occurrence of paragangliomas in areas with no known paraganglionic tissue like the nasal cavity $[13,29,42,44]$. Additionally, it has been shown that paraganglionic tissue exists around the terminal portion of the maxillary artery in infants and could possibly represent a point of origin for paragangliomas in the nasal cavity due to its anatomic proximity [19, 45]. Others have suggested that the paraganglionic tissue may exist in the pterygopalatine fossa due to the close relationship of paraganglionic tissue with arteries and cranial nerves $[18,19,22]$.

In contrast, chondrocytes of the cartilaginous septum develop from neural crest cells between the nasal cavities by the ninth week of embryonic development $[46,47]$. This is evident by the expression of various neural crest stem cell markers in nasal septum progenitor cells [48]. Several studies have demonstrated that these neural crest-derived chondrocytes in an adult septum retain pluripotent properties, with the capacity for osteogenic, chondrogenic, and neurogenic differentiation $[48,49]$. It is possible that the neural crest origin of septal chondrocytes plays an important factor in the development of nasal septal paragangliomas. 


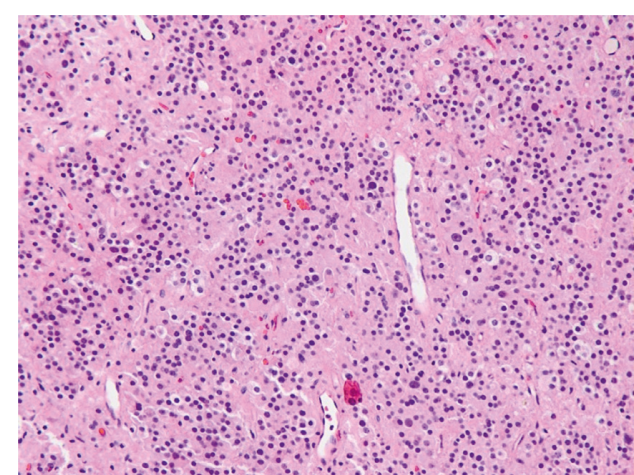

(a)

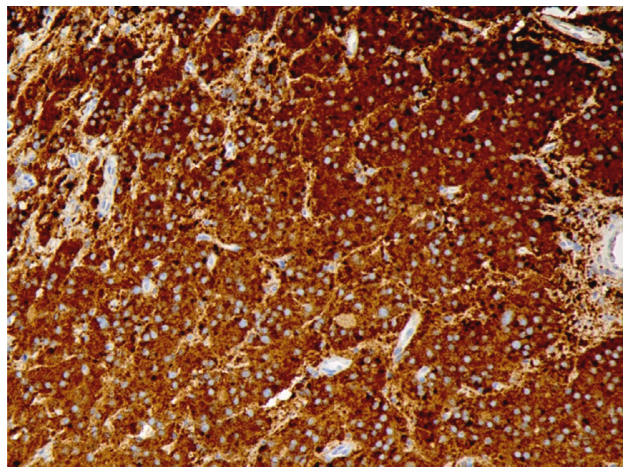

(c)

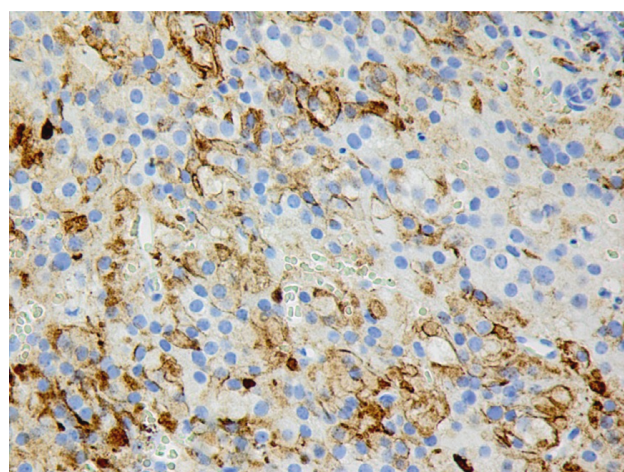

(b)

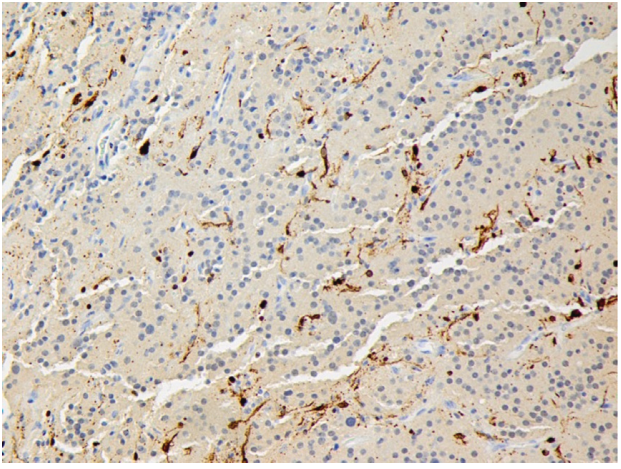

(d)

FIGURE 3: (a) HeE of the septal mass showing a "zellballen” pattern of clusters of epithelioid cells between bands of fibrillary stroma (20x). IHC staining showing positivity for (b) chromogranin A within epithelioid cells (40x), (c) synaptophysin within epithelioid cells (20x), and (d) S-100 within fibrillary cells (20x).

TABLE 1: Review of reported cases of sinonasal paragangliomas.

\begin{tabular}{|c|c|c|c|c|c|c|c|c|}
\hline Case & Author & Year & Sex & Age & Location & Biological behavior & Therapy & Follow-up \\
\hline 1 & Harkins [9] & 1957 & $\mathrm{~F}$ & 52 & Ethmoid sinus & Benign & Exc, RT, lig ECA & NED at 1 year \\
\hline 2 & Moran [10] & 1962 & $\mathrm{~F}$ & 89 & Nasal cavity & Benign & $\begin{array}{l}\text { Exc, ligation of external } \\
\text { carotid artery }\end{array}$ & NED at 2 years \\
\hline 3 & Lack [3] & 1976 & $\mathrm{~F}$ & 50 & High nasal vault & $\begin{array}{l}\text { Benign (local recurrence } \\
\mathrm{x} 3 \text { ) }\end{array}$ & $\begin{array}{l}\text { Exc, ligation of external } \\
\text { carotid artery }\end{array}$ & $\begin{array}{c}\text { NED at } 11 \text { years } \\
\text { following final } \\
\text { exc }\end{array}$ \\
\hline 4 & & & $\mathrm{~F}$ & 50 & Middle turbinate & Benign & Exc & No f/u \\
\hline 5 & & & M & 8 & Middle turbinate & Benign & Exc & NED at 7 years \\
\hline 6 & Gosavi [11] & 1978 & M & 65 & Middle turbinate & Benign & $\begin{array}{c}\text { Exc, RT (incomplete } \\
\text { cycle) }\end{array}$ & NED at 2 years \\
\hline 7 & Apple [12] & 1982 & $\mathrm{~F}$ & 50 & $\begin{array}{l}\text { Ethmoid, sphenoid, and } \\
\text { maxillary sinuses }\end{array}$ & $\begin{array}{l}\text { Benign; ectopic ACTH } \\
\text { production }\end{array}$ & $\begin{array}{l}\text { Exc, RT, hormonal } \\
\text { pharmacotherapy }\end{array}$ & NED at 6 years \\
\hline 8 & Koegel [13] & 1982 & $\mathrm{~F}$ & 71 & $\begin{array}{l}\text { Maxillary and sphenoid } \\
\text { sinuses }\end{array}$ & $\begin{array}{l}\text { Malignant (extension } \\
\text { into temporal lobe); } \\
\text { catecholamine secretion }\end{array}$ & RT & $\begin{array}{l}\text { No follow-up } \\
\text { available }\end{array}$ \\
\hline 9 & $\begin{array}{l}\text { Himelfarb } \\
{[14]}\end{array}$ & 1985 & M & 41 & Middle turbinate & Benign & Exc & NED at 1 year \\
\hline 10 & Straehler [15] & 1985 & $\mathrm{M}$ & 42 & Maxillary sinus & Benign & Exc & $\begin{array}{l}\text { No follow-up } \\
\text { available }\end{array}$ \\
\hline 11 & Ueda [16] & 1985 & $\mathrm{~F}$ & 31 & $\begin{array}{l}\text { Maxillary and ethmoid } \\
\text { sinuses }\end{array}$ & Benign & Exc & NED at 2.5 years \\
\hline 12 & Watson [17] & 1988 & M & 56 & Inferior turbinate & Benign & Exc, RT & NED at 3 years \\
\hline 13 & Branham [18] & 1989 & $\mathrm{~F}$ & 25 & $\begin{array}{l}\text { Maxillary and ethmoid } \\
\text { sinuses }\end{array}$ & $\begin{array}{l}\text { Malignant (brain } \\
\text { metastasis) }\end{array}$ & Exc, RT, CT & DOD at 3 years \\
\hline 14 & Kuhn [19] & 1989 & M & 62 & $\begin{array}{l}\text { Superior nasal cavity, } \\
\text { ethmoid sinus }\end{array}$ & Benign & Exc & NED at 1 year \\
\hline
\end{tabular}


TABle 1: Continued.

\begin{tabular}{|c|c|c|c|c|c|c|c|c|}
\hline Case & Author & Year & Sex & Age & Location & Biological behavior & Therapy & Follow-up \\
\hline 15 & Shimoda [20] & 1989 & M & 58 & $\begin{array}{l}\text { Ethmoid sinus and } \\
\text { bilateral frontal fossa }\end{array}$ & $\begin{array}{c}\text { Malignant (cervical } \\
\text { lymph nodes metastasis) }\end{array}$ & Exc, RT & NED at 2 years \\
\hline 16 & Talbot [21] & 1990 & $\mathrm{~F}$ & 17 & Maxillary sinus & Benign & $\begin{array}{l}\text { Embolization of internal } \\
\text { maxillary artery, exc }\end{array}$ & NED at 3 months \\
\hline 17 & Nguyen [22] & 1995 & $\mathrm{~F}$ & 32 & Ethmoid sinus & $\begin{array}{l}\text { Malignant (bone } \\
\text { metastasis) }\end{array}$ & Exc, RT & DOD at 15 years \\
\hline 18 & Biswas [23] & 1999 & $\mathrm{~F}$ & 45 & Middle turbinate & Benign & Exc & NED at 1 month \\
\hline 19 & Sharma [24] & 1999 & M & 33 & $\begin{array}{l}\text { Frontal sinus (primary); } \\
\text { orbit, optic nerve, } \\
\text { cavernous sinus, } \\
\text { maxillary and ethmoid } \\
\text { sinuses (recurrent) }\end{array}$ & $\begin{array}{l}\text { Malignant (recurrence, } \\
\text { intracranial invasion) }\end{array}$ & $\begin{array}{l}\mathrm{CT}, \mathrm{RT} \text {, exc; vessel } \\
\text { embolization, exc } \\
8 \text { months later for } \\
\text { recurrence }\end{array}$ & $\begin{array}{l}\text { DOD at } 19 \\
\text { months }\end{array}$ \\
\hline 20 & $\begin{array}{l}\text { Welkoborsky } \\
\text { [25] }\end{array}$ & 2000 & $\mathrm{~F}$ & 54 & Nasal cavity & Benign & Exc & NED at 3 years \\
\hline 21 & & & $\mathrm{~F}$ & 56 & Ethmoid sinus & $\begin{array}{l}\text { Malignant (brain } \\
\text { metastasis) }\end{array}$ & Exc, RT & $\begin{array}{l}\text { DOD at } 28 \\
\text { months }\end{array}$ \\
\hline 22 & & & M & 57 & Ethmoid sinus & Benign & Exc, RT & NED at 2 years \\
\hline 23 & Scott $[26]$ & 2001 & M & 24 & $\begin{array}{l}\text { Nasal cavity, ethmoid } \\
\text { sinus }\end{array}$ & Benign & Exc & $\begin{array}{l}\text { NED at } 15 \\
\text { months }\end{array}$ \\
\hline 24 & Lecuna [27] & 2002 & $\mathrm{~F}$ & 72 & $\begin{array}{l}\text { Ethmoid sinus } \\
\text { (primary); maxillary } \\
\text { sinus (recurrent) }\end{array}$ & $\begin{array}{l}\text { Malignant (recurrence, } \\
\text { submandibular lymph } \\
\text { nodes metastasis) }\end{array}$ & Exc & $\begin{array}{l}\text { No follow-up } \\
\text { available }\end{array}$ \\
\hline 25 & Ketabchi [28] & 2003 & $\mathrm{~F}$ & 72 & Nasal cavity & Benign & Exc & NED at 8 months \\
\hline 26 & Mouadeb [29] & 2003 & M & 72 & Ethmoid sinus & Benign & Exc & NED at 4 years \\
\hline 27 & $\begin{array}{l}\text { Lieberum } \\
{[30]}\end{array}$ & 2003 & M & 64 & $\begin{array}{c}\text { Frontal and ethmoid } \\
\text { sinuses }\end{array}$ & $\begin{array}{l}\text { Benign; ectopic ACTH } \\
\text { production }\end{array}$ & Exc & NED at 2 years \\
\hline 28 & Askar [31] & 2003 & M & 47 & Middle turbinate & Benign & Exc & NED at 2 years \\
\hline 29 & Rocha [32] & 2005 & M & 45 & Nasal cavity & Benign & Exc & NED at 5 months \\
\hline 30 & Liess [33] & 2007 & F & 64 & $\begin{array}{l}\text { Sphenoid sinus, sella, } \\
\text { cavernous sinus }\end{array}$ & Benign & Partial exc, RT & $\begin{array}{l}\text { Residual tumor } \\
\text { stable at } 2 \text { years }\end{array}$ \\
\hline 31 & Morales [7] & 2007 & $\mathrm{~F}$ & 41 & $\begin{array}{l}\text { Sphenoid and ethmoid } \\
\text { sinuses }\end{array}$ & Benign & No information available & $\begin{array}{l}\text { No follow-up } \\
\text { available }\end{array}$ \\
\hline 32 & Jin [34] & 2008 & $\mathrm{~F}$ & 23 & Superior turbinate & $\begin{array}{l}\text { Malignant (questionable } \\
\text { transformation } \\
\text { simulating Ewing's } \\
\text { sarcoma/primitive } \\
\text { neuroectodermal tumor) }\end{array}$ & Exc & NED at 3 years \\
\hline 33 & Fasunla [35] & 2008 & $\mathrm{~F}$ & 39 & Lateral nasal wall & Benign & Exc & NED at 1 year \\
\hline 34 & Kisser [6] & 2012 & F & 36 & Maxillary sinus & Benign & Exc & NED at 1 year \\
\hline 35 & Zainine [36] & 2012 & $\mathrm{~F}$ & 43 & Middle turbinate & Benign & Exc & NED at 2 years \\
\hline 36 & $\begin{array}{c}\text { Papaspyrou } \\
{[4]}\end{array}$ & 2013 & $\mathrm{~F}$ & 33 & Nasal cavity & Benign & Exc & NED at 15 years \\
\hline 37 & & & M & 64 & $\begin{array}{l}\text { Ethmoid sinuses, } \\
\text { anterior skull base, } \\
\text { frontal lobe dura } \\
\text { (primary); ethmoid, } \\
\text { sphenoid, cavernous } \\
\text { sinus, orbit (recurrent) }\end{array}$ & $\begin{array}{l}\text { Malignant (recurrent, } \\
\text { intradural metastases) }\end{array}$ & 2 exc, RT, CT & $\begin{array}{l}\text { DOD at } 60 \\
\text { months }\end{array}$ \\
\hline 38 & & & $\mathrm{~F}$ & 56 & Ethmoid sinus & $\begin{array}{l}\text { Malignant (brain } \\
\text { metastasis) }\end{array}$ & Exc, RT & $\begin{array}{l}\text { DOD at } 28 \\
\text { months }\end{array}$ \\
\hline 39 & & & $\mathrm{~F}$ & 80 & $\begin{array}{l}\text { Nasal cavity, } \\
\text { maxilloethmoidal angle, } \\
\text { maxillary, ethmoid, and } \\
\text { sphenoid sinuses } \\
\text { (primary); nasal cavity, } \\
\text { anterior skull base, } \\
\text { frontal lobe (recurrent) }\end{array}$ & $\begin{array}{l}\text { Malignant (recurrent, } \\
\text { intracranial invasion) }\end{array}$ & Exc & $\begin{array}{c}\text { DNOD } 17 \\
\text { months after } 2 \text { nd } \\
\text { surgery }\end{array}$ \\
\hline 40 & & & $\mathrm{M}$ & 57 & Ethmoid sinus & Benign & Exc & NED at 2 years \\
\hline 41 & & & F & 54 & Nasal cavity & Benign & Exc & NED at 3 years \\
\hline 42 & Granato [5] & 2013 & F & 61 & Nasal cavity & Benign & Exc & $\mathrm{NED}$ at 2 years \\
\hline
\end{tabular}


TABLE 1: Continued.

\begin{tabular}{|c|c|c|c|c|c|c|c|c|}
\hline Case & Author & Year & Sex & Age & Location & Biological behavior & Therapy & Follow-up \\
\hline 43 & Michel [37] & 2013 & $\mathrm{M}$ & 47 & Maxillary sinus & $\begin{array}{l}\text { Malignant (cervical } \\
\text { lymph node metastasis) }\end{array}$ & Exc, RT & NED at 1 year \\
\hline 44 & $\begin{array}{c}\text { Amiraraghi } \\
{[38]}\end{array}$ & 2013 & $\mathrm{M}$ & 29 & $\begin{array}{l}\text { Cribriform plate and } \\
\text { fovea ethmoidalis } \\
\text { presenting as nasal } \\
\text { polyps }\end{array}$ & Benign & Exc & NED at 3 years \\
\hline 45 & Arora [39] & 2014 & $\mathrm{~F}$ & 40 & Lateral nasal wall & Benign & Exc & NED at 2 years \\
\hline 46 & $\begin{array}{l}\text { Yamaguchi } \\
{[40]}\end{array}$ & 2015 & $\mathrm{~F}$ & 66 & Ethmoid sinus & Benign & Exc & NED at 1 year \\
\hline 47 & Aydin [41] & 2015 & $\mathrm{~F}$ & 32 & $\begin{array}{l}\text { Nasal cavity, ethmoid } \\
\text { sinus }\end{array}$ & $\begin{array}{l}\text { Benign (local recurrence } \\
\qquad \mathrm{x} 2 \text { ) }\end{array}$ & Exc & $\begin{array}{l}\text { NED } 5 \text { years after } \\
\text { final exc }\end{array}$ \\
\hline 48 & Srivastava [8] & 2016 & $\mathrm{M}$ & 60 & Anterior nasal septum & Benign & Exc & $\begin{array}{l}\text { NED at } 18 \\
\text { months }\end{array}$ \\
\hline
\end{tabular}

RT, radiation therapy; CT, chemotherapy; Exc, surgical excision; NED, no evidence of disease; DOD, died of disease.

Despite the neural crest origins of nasal chondrocytes, paragangliomas arising from the nasal septum are extremely rare.

Masses arising from the nasal septum represent a broad spectrum of diagnoses including polyps, chondromas, hematomas, and hemangiomas. Less common septal lesions include sarcomas, melanomas, and other neoplasms $[46,50]$. Patients with septal masses typically present with nonspecific symptoms of nasal obstruction or epistaxis, making it difficult to diagnose these masses based on clinical evaluation alone. CT imaging and MR imaging are useful tools in determining exact locations and boundaries of lesions, as well as identifying any erosion or extension into surrounding structures, though imaging features of most masses are nondiagnostic. Diagnosis of such masses requires a combination of clinical history and histopathologic findings. Although paragangliomas of the nasal septum are extremely rare, they should be included in the differential diagnosis when evaluating a septal mass.

The classical histologic appearance of a paraganglioma features an alveolar pattern of well-defined clusters of epithelioid chief cells with round nuclei and eosinophilic cytoplasm. These cells form a "zellballen" pattern of nests separated by vascular stroma and spindle-shaped sustentacular cells [28, 43]. Immunohistochemical staining of paragangliomas generally demonstrates positive markers for NSE, synaptophysin, and chromogranin within the chief cells and S-100 and GFAP within the sustentacular cells [8, 25, 43].

Although the majority of reported nasal paragangliomas are benign, 12 of the cases presented in this review $(25.0 \%)$ were reported to be malignant, demonstrating intracranial invasion and/or metastasis to the brain, cervical lymph nodes, and bones. It is widely accepted that malignancy cannot be diagnosed by histology alone, but requires evidence of bony invasion or distant metastasis [18, 19, 22]. Certain histological features such as mitotic figures, cellular pleomorphism, necrosis, and vascular invasion can be suggestive of malignancy, though none of these features have been shown to be reliable predictors of malignancy $[19,51]$. As such, evaluation with CT imaging and MRI imaging plays a key role in both localization of the primary tumor and identification of local invasion or metastasis.
Almost all of the cases presented in this review were treated surgically. Suggested management of sinonasal paragangliomas involves surgical excision with close followup, as several cases of recurrence have been reported $[4,22,29]$. Due to the rich vascularity of these masses, preoperative embolization of the vessels supplying the tumor has been suggested to reduce bleeding during surgery $[4,22,24]$. Many authors suggest the use of radiation therapy to slow the rate of recurrence, although radiation therapy alone has not been shown to be curative $[3,22,33]$. Chemotherapy as a primary treatment for these tumors has been shown to be largely ineffective, though 3 cases reported in this review reported the use of chemotherapy in addition to surgery and radiation therapy in the management of malignant sinonasal paragangliomas $[4,22]$.

\section{Conclusion}

We present a rare case of a paraganglioma presenting as a septal mass. To the best of the authors' knowledge, only one other case of nasal septal paragangliomas has been reported. Clinically, these lesions cause symptoms of obstruction, congestion, headache, and epistaxis. Recognizing that paragangliomas can arise from the nasal septum is crucial to accurately diagnose these tumors when evaluating septal lesions. A diagnosis of a paragangliomas can be confirmed based on the histopathologic imaging. These tumors are usually benign but require additional imaging as malignancy cannot reliably be ruled out on the basis of histology alone. Treatment of these tumors requires surgical resection, though radiation therapy has been to show slow growth and decrease recurrence.

\section{Conflicts of Interest}

The authors declare that there are no conflicts of interest or financial disclosures.

\section{Acknowledgments}

The authors thank Dr. David Yau for providing the histopathology images and Dr. John Go for reviewing the radiology images. 


\section{References}

[1] C. Offergeld, C. Brase, S. Yaremchuk et al., "Head and neck paragangliomas: clinical and molecular genetic classification," Clinics, vol. 67, no. 1, pp. 19-28, 2012.

[2] J. H. Lee, F. Barich, L. H. Karnell et al., "National Cancer Data Base report on malignant paragangliomas of the head and neck," Cancer, vol. 94, no. 3, pp. 730-737, 2002.

[3] E. E. Lack, A. L. Cubilla, J. M. Woodruff, and H. W. Farr, "Paragangliomas of the head and neck region: a clinical study of 69 patients," Cancer, vol. 39, no. 2, pp. 397-409, 1977.

[4] K. Papaspyrou, H. J. Welkoborsky, H. Gouveris, and W. J. Mann, "Malignant and benign sinonasal paragangliomas," Laryngoscope, vol. 123, no. 8, pp. 1830-1836, 2013.

[5] L. Granato, J. D. Prospero, and D. M. Filho, "Nasal paraganglioma: a case report and literature review," International Archives of Otorhinolaryngology, vol. 17, no. 1, pp. 92-95, 2013.

[6] U. Kisser, T. Braun, D. Mayr, and A. Leunig, "Paraganglioma of the maxillary sinus," Auris Nasus Larynx, vol. 40, no. 5, pp. 506-509, 2013.

[7] H. Morales, M. Castillo, and V. Jewells, "Paraganglioma of the sphenoid sinus: case report and review of literature," Clinical Imaging, vol. 31, no. 1, pp. 32-36, 2007.

[8] R. Srivastava, N. Wadhwa, S. Gupta, and U. Razdan, "Nasal polyp-an incidental paraganglioma," Turkish Journal of Pathology, vol. 32, no. 3, pp. 196-199, 2016.

[9] W. B. Harkins, "Nonchromaffin paraganglioma of the nasal sinuses," Laryngoscope, vol. 67, no. 3, pp. 246-259, 1957.

[10] T. E. Moran, "Nonchromaffin paraganglioma of the nasal cavity," Laryngoscope, vol. 72, no. 2, pp. 201-206, 1962.

[11] D. K. Gosavi and A. T. Mohidekar, "Chemodectoma of the nose and sphenoid sinus," Journal of Laryngology \& Otology, vol. 92, no. 9, pp. 813-816, 1978.

[12] D. Apple and K. Kreines, "Cushing's syndrome due to ectopic ACTH production by a nasal paraganglioma," American Journal of the Medical Sciences, vol. 283, no. 1, pp. 32-35, 1982.

[13] L. J. Koegel, H. L. Levine, and S. R. Waldman, "Paraganglioma of the sphenoid sinus appearing as labile hypertension," Otolaryngology-Head and Neck Surgery, vol. 90, no. 6, pp. 704-707, 1982.

[14] M. Z. Himelfarb, N. L. Ostrzega, J. Samuel, and E. Shanon, "Paraganglioma of the nasal cavity," Laryngoscope, vol. 93, no. 3, pp. 350-352, 1983.

[15] H. J. Straehler-Pohl, "Paraganglioma of the nasal cavity," Laryngologie, Rhinologie, Otologie, vol. 64, no. 8, pp. 399-402, 1985.

[16] N. Ueda, A. Yoshida, R. Fukunishi, H. Fujita, and N. Yanagihara, "Nonchromaffin paraganglioma in the nose and paranasal sinuses," Pathology International, vol. 35, no. 2, pp. 489-495, 1985.

[17] D. J. Watson, "Nasal paraganglioma," Journal of Laryngology \& Otology, vol. 102, no. 6, pp. 526-529, 1988.

[18] G. H. Branham, D. R. Gnepp, S. O'McMenomey, and W. H. Friedman, "Malignant paraganglioma-a case report and literature review," Otolaryngology-Head and Neck Surgery, vol. 101, no. 1, pp. 99-103, 1989.

[19] J. A. Kuhn and B. L. Aronoff, "Nasal and nasopharyngeal paraganglioma," Journal of Surgical Oncology, vol. 40, no. 1, pp. 38-45, 1989.

[20] M. Shimoda, N. Shibuya, and O. Sato, "Nasal cavity paraganglioma with intracranial extension," Neurologia medicochirurgica, vol. 29, no. 2, pp. 132-136, 1989.
[21] A. R. Talbot, "Paraganglioma of the maxillary sinus," Journal of Laryngology \& Otology, vol. 104, no. 3, pp. 248-251, 1990.

[22] Q. A. Nguyen, P. M. Gibbs, and D. H. Rice, "Malignant nasal paraganglioma: a case report and review of the literature," Otolaryngology-Head and Neck Surgery, vol. 113, no. 1, pp. 157-161, 1995.

[23] A. Biswas and R. Pal, "Paraganglioma of nasal gavity," Indian Journal of Otolaryngology and Head \& Neck Surgery, vol. 52, no. 1, pp. 63-64, 1999.

[24] H. S. Sharma, M. Madhavan, N. H. Othman, M. Muhamad, and J. M. Abdullah, "Malignant paraganglioma of frontoethmoidal region," Auris Nasus Larynx, vol. 26, no. 4, pp. 487-493, 1999.

[25] H. J. Welkoborsky, J. Gosepath, R. Jacob, W. J. Mann, and R. G. Amedee, "Biologic characteristics of paragangliomas of the nasal cavity and paranasal sinuses," American Journal of Rhinology, vol. 14, no. 6, pp. 419-426, 2000.

[26] M. Scott, D. S. Brooker, and R. I. Davis, "Paraganglioma of the nasal cavity," Ulster Medical Journal, vol. 70, no. 2, pp. 149151, 2001.

[27] J. B. Lecanu, S. Arkwright, P. H. Halimi, J. Trotoux, and P. Bonfils, "Multifocal malignant paraganglioma of the paranasal sinuses: a case report," Otolaryngology-Head and Neck Surgery, vol. 126, no. 4, pp. 445-447, 2002.

[28] S. Ketabchi, D. Massi, R. Santoro, and A. Franchi, "Paraganglioma of the nasal cavity: a case report," European Archives of Oto-Rhino-Laryngology, vol. 260, no. 6, pp. 336-340, 2003.

[29] D. A. Mouadeb, R. K. Chandra, D. W. Kennedy, and M. Feldman, "Sinonasal paraganglioma: endoscopic resection with a 4-year follow-up," Head and Neck, vol. 25, no. 12, pp. 1077-1081, 2003.

[30] B. Lieberum, C. Jaspers, and R. Munzenmaier, "ACTHproducing paraganglioma of the paranasal sinuses," HNO, vol. 51, no. 4, pp. 328-331, 2003.

[31] I. Askar, M. F. Oktay, and N. Kilinc, "Use of radial forearm free flap with palmaris longus tendon in reconstruction of total maxillectomy with sparing of orbital contents," Journal of Craniofacial Surgery, vol. 14, no. 2, pp. 220-227, 2003.

[32] M. P. Rocha, A. M. Campagnolo, V. S. Macedo, F. B. Scarton, H. P. Rocha, and G. Kuhl, "Nasal paraganglioma: a case report," Brazilian Journal of Otorhinolaryngology, vol. 71, no. 2, pp. 237-240, 2005.

[33] B. D. Liess, J. A. Horst, and R. P. Zitsch III, "Sphenoid sinus paraganglioma: first reported case," American Journal of Otolaryngology, vol. 28, no. 5, pp. 347-349, 2007.

[34] H. R. Jin, O. J. Lee, and Y. Ahn, "Nasal cavity paraganglioma with malignant transformation: a case report," Auris Nasus Larynx, vol. 35, no. 1, pp. 137-139, 2008.

[35] A. J. Fasunla, T. S. Ibekwe, O. A. Afolabi et al., "Sinonasal paraganglioma: a case report," Oral and Maxillofacial Surgery, vol. 12, no. 2, pp. 93-96, 2008.

[36] R. Zainine, S. Sahtout, H. Ouertani, M. Sellami, N. Beltaief, and G. Besbes, "Paraganglioma of the nasal cavity," Journal Medical Tunisie, vol. 90, no. 2, pp. 178-179, 2012.

[37] J. Michel, D. Taieb, M. Jolibert et al., "Sinonasal paraganglioma with long-delayed recurrence and metastases: genetic and imaging findings," Journal of Clinical Endocrinology \& Metabolism, vol. 98, no. 11, pp. 4262-4266, 2013.

[38] N. Amiraraghi, M. I. Syed, S. Syed, and A. T. Williams, "Paraganglioma of the skull base presenting as nasal polyps," Laryngoscope, vol. 123, no. 3, pp. 577-580, 2013.

[39] V. Arora, P. Verma, P. P. Singh, N. Wadhwa, and K. Bhatia, "Sinonasal paraganglioma: a case report and review of 
literature," Clinical Rhinology An International Journal, vol. 7, no. 2, pp. 87-89, 2014.

[40] W. Yamaguchi, D. Asaka, K. Wada, T. Okushi, and N. Otori, "A case of paraganglioma of the paranasal sinus operated by endoscopic sinus surgery," Oto-Rhino-Laryngology Tokyo, vol. 58, no. 4, pp. 18-23, 2015.

[41] S. Aydin, B. Karabulut, K. S. Orhan, I. Kilicaslan, and K. Deger, "A case of sinonasal paraganglioma with a different morphology: nine-year follow-up," Turkish Journal of Ear Nose and Throat, vol. 25, no. 1, pp. 43-45, 2015.

[42] K. C. Ho, G. Meyer, J. Garancis, and J. Hanna, "Chemodectoma involving the cavernous sinus and semilunar ganglion," Human Pathology, vol. 13, no. 10, pp. 942-943, 1982.

[43] P. G. Wasserman and P. Savargaonkar, "Paragangliomas: classification, pathology, and differential diagnosis," Otolaryngologic Clinics of North America, vol. 34, no. 5, pp. 845-862, 2001.

[44] J. M. Sykes and R. H. Ossoff, "Paragangliomas of the head and neck," Otolaryngologic Clinics of North America, vol. 19, no. 4, pp. 755-767, 1986.

[45] I. H. Girgis and S. A. Fahmy, "Nasopharyngeal fibroma: its histo-pathological nature," Journal of Laryngology \& Otology, vol. 87, no. 11, pp. 1107-1123, 1973.

[46] M. P. Valencia and M. Castillo, "Congenital and acquired lesions of the nasal septum: a practical guide for differential diagnosis," RadioGraphics, vol. 28, no. 1, pp. 205-223, 2008.

[47] D. Neskey, J. A. Eloy, and R. R. Casiano, "Nasal, septal, and turbinate anatomy and embryology," Otolaryngologic Clinics of North America, vol. 42, no. 2, pp. 193-205, 2009.

[48] A. Shafiee, M. Kabiri, N. Ahmadbeigi et al., "Nasal septumderived multipotent progenitors: a potent source for stem cellbased regenerative medicine," Stem Cells and Development, vol. 20, no. 12, pp. 2077-2091, 2011.

[49] K. Pelttari, M. Mumme, A. Barbero, and I. Martin, "Nasal chondrocytes as a neural crest-derived cell source for regenerative medicine," Current Opinion in Biotechnology, vol. 47, pp. 1-6, 2017.

[50] G. Yamin, A. Shabaik, and M. Mafee, "Mass of the anterior nasal septum," JAMA Otolaryngology-Head \& Neck Surgery, vol. 142, no. 6, pp. 601-602, 2016.

[51] R. I. Linnoila, H. R. Keiser, S. M. Steinberg, and E. E. Lack, "Histopathology of benign versus malignant sympathoadrenal paragangliomas: clinicopathologic study of 120 cases including unusual histologic features," Human Pathology, vol. 21, no. 11, pp. 1168-1180, 1990. 


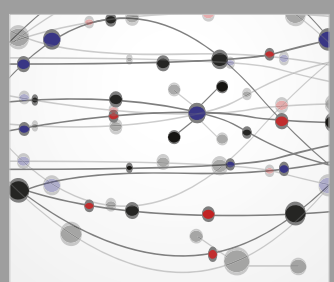

The Scientific World Journal
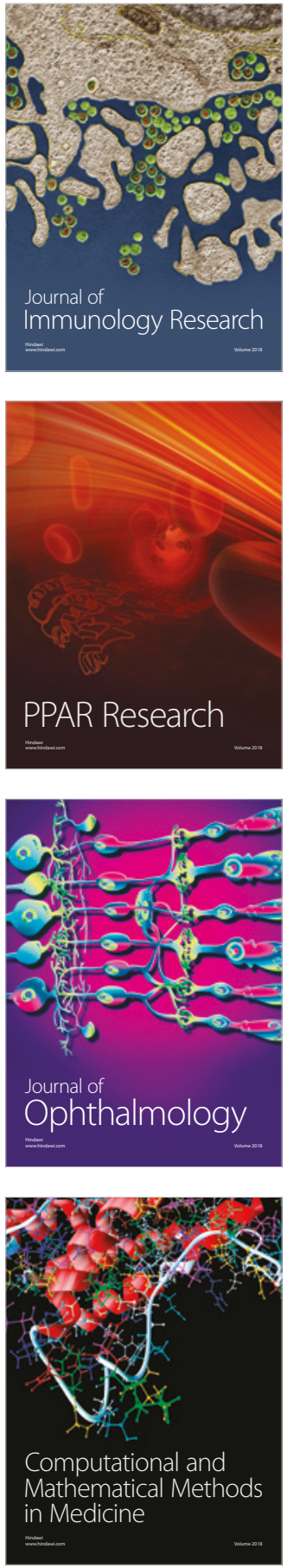

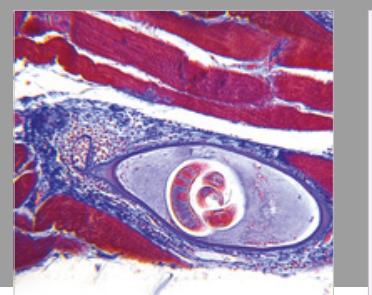

Gastroenterology Research and Practice

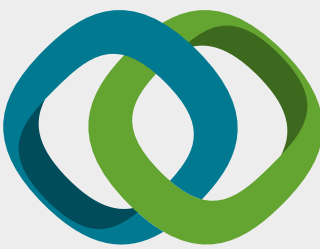

\section{Hindawi}

Submit your manuscripts at

www.hindawi.com
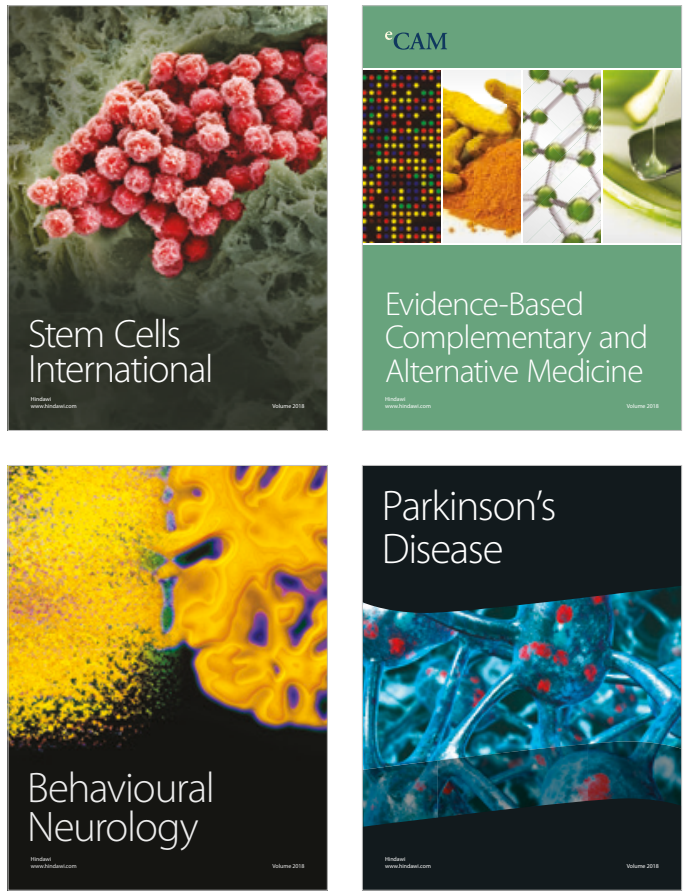

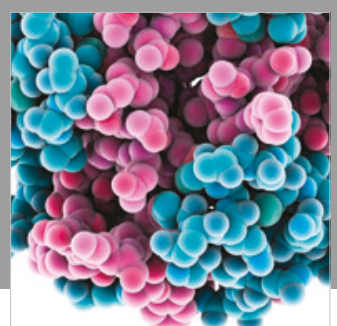

ournal of

Diabetes Research

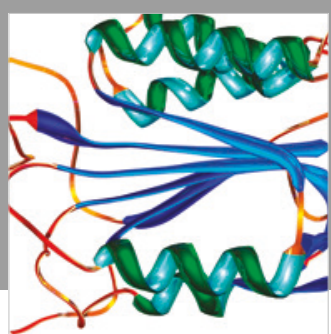

Disease Markers
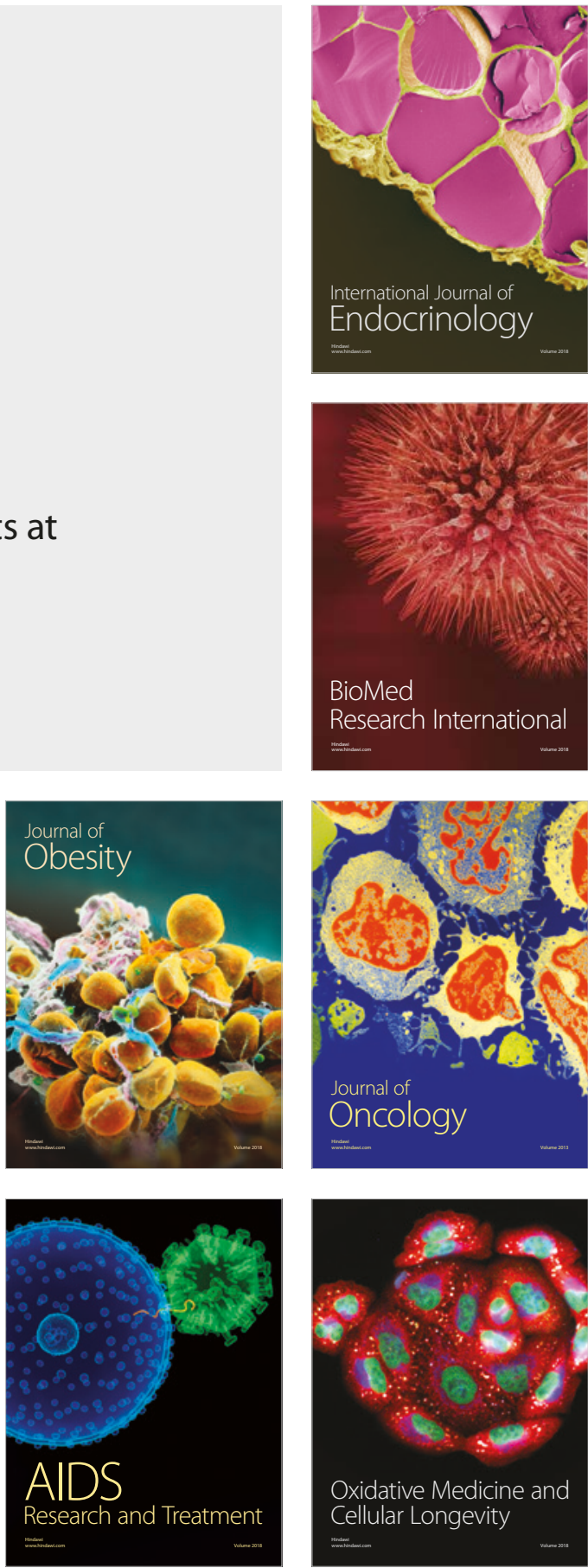